Philosophical Issues in Nursing 
Also by Steven D. Edwards

Nursing Ethics: A Principle-based Approach (1996)

Externalism in the Philosophy of Mind (1994)

Relativism, Conceptual Schemes and Categorial Frameworks (1990) 


\title{
Philosophical Issues in Nursing
}

\author{
Edited by
}

\author{
Steven D. Edwards
}

RMN, BA (hons), MPhil, PhD 


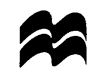

(C) Selection, editorial matter, Introduction, Editor's Introductions to all chapters: Steven D. Edwards 1998

(C) Chapters (in order): Joan Liaschenko, Keith Cash, Trevor Hussey, Simon Woods, Steven D. Edwards, Edward Lepper, Stephen Horrocks, Janet Holt, Paul J. Dawson, Philip J. Ross 1998

All rights reserved. No reproduction, copy or transmission of this publication may be made without written permission.

No paragraph of this publication may be reproduced, copied or transmitted save with written permission or in accordance with the provisions of the Copyright, Designs and Patents Act 1988, or under the terms of any licence permitting limited copying issued by the Copyright Licensing Agency, 90 Tottenham Court Road, London W1P 9HE.

Any person who does any unauthorised act in relation to this publication may be liable to criminal prosectuion and civil claims for damages.

The authors have asserted their rights to be identified as the authors of this work in accordance with the Copyright, Designs and Patents Act 1988.

First published 1998 by

MACMILLAN PRESS LTD

Houndmills, Basingstoke, Hampshire RG21 6XS

and London

Companies and representatives

throughout the world

ISBN 978-0-333-67210-5 ISBN 978-1-349-14235-4 (eBook)

DOI 10.1007/978-1-349-14235-4

A catalogue record for this book is available from the British Library.

This book is printed on paper suitable for recycling and made from fully managed and sustained forest sources.

$\begin{array}{llllllllll}10 & 9 & 8 & 7 & 6 & 5 & 4 & 3 & 2 & 1\end{array}$

$\begin{array}{llllllllll}07 & 06 & 05 & 04 & 03 & 02 & 01 & 00 & 99 & 98\end{array}$

Editing and origination by Aardvark Editorial, Mendham, Suffolk 
Notes on the contributors

vii

List of figures

Introduction

Part I: Nursing Practice and Knowledge

1 The shift from the closed to the open body - ramifications for nursing testimony Joan Liaschenko

2 Traditions and practice - nursing theory and political philosophy Keith Cash

3 Change and nursing Trevor Hussey

Part II: Conceptual Foundations

4 Holism in nursing Simon Woods

5 Positivism as a method in nursing research

Steven Edwards

6 Towards a credible theory of mind for nursing

Edward Lepper

Part III: The Nurse Curriculum

7 Heidegger and the nurse curriculum Stephen Horrocks

8 The unexamined life is not worth living Janet Holt

Part IV: The Self in Nursing

9 The self Paul Dawson

10 The self and compulsory treatment Philip Ross 


\section{NOTES ON THE CONTRIBUTORS}

\section{Keith Cash}

RGN, RMN, BA(HONS), MSc, PHD

Occupation:

Professor of Nursing, Faculty of Health and Social Care, Leeds Metropolitan University.

Recent Publications: Cash K. et al. The Preparation of Sick Children's Nurses to Care for Children in the Community (London: ENB, 1995). Benner and expertise in nursing: a critique, International Journal of Nursing Studies, 32(6): 527-34, 1996. Social epistemology, gender and nursing theory, International Journal of Nursing Studies, 34(2): 137-43, 1997.

\section{Paul J. Dawson}

RPN, BA(HONS), MA

Occupation:

Research nurse, Psychiatric Nursing Research Institute, Royal Park Hospital, Melbourne, Australia.

Recent Publications: The impact of biological psychiatry on psychiatric nursing, Journal of Psychosocial Nursing, 34(8): 28-33, 1996. In defence of the middle ground, Journal of Advanced Nursing, 19: 1015-23, 1994. Philosophy, biology, and mental disorder, Journal of Advanced Nursing, 20: 587-90, 1995. Contra biology: a polemic, Journal of Advanced Nursing, 20: 1094-103, 1995.

\section{Steven D. Edwards}

RMN, BA(HONS), MPHIL, PHD

Occupation: Lecturer, Centre for Philosophy and Health Care, University of Wales, Swansea.

Recent Publications: Externalism in the Philosophy of Mind (Aldershot: Avebury, 1994). Nursing Ethics, A Principle-based Approach (London: Macmillan, 1996). What is philosophy of nursing?, Journal of Advanced Nursing, 25: 1089-93, 1997. 


\section{Janet Holt}

RGN, RM, ADM, RNT, PGDIPE, BA(HONS), MPHIL

Occupation:

Lecturer, School of Healthcare Studies, University of Leeds.

Recent Publications: Ethics, Law and Nursing (co-authored) (Manchester: Manchester University Press, 1995). Screening and the perfect baby, in Frith, L. (ed.) Midwifery Ethics (London: ButterworthHeineman, 1996).

\section{Stephen Horrocks}

RMN, RGN, BA(HONS), MPHIL (PHD CANDIDATE)

Occupation: Senior Lecturer in Mental Health Nursing, Department of Nursing, University of Salford.

\section{Trevor Hussey}

BA(HONS), MA, DPHIL

Occupation:

Senior Lecturer in Philosophy, Buckinghamshire College of Higher Education.

Recent Publications: Nursing ethics and project 2000, Journal of Advanced Nursing, 15: 1377-82, 1990. Nursing ethics and codes of professional conduct, Nursing Ethics, 3(3): 250-8, 1996. Efficiency and health, Nursing Ethics, 4(3): 181-90, 1997.

\section{Edward P.R. Lepper}

BA(HONS)

Occupation: $\quad$ Lecturer in Philosophy, Buckinghamshire College of Higher Education.

Recent Publications: What's wrong with diversity?, Proceedings of Consensus in Bioethics conference, University of Central Lancashire, 1996.

\section{Joan Liaschenko}

RN, MA, MS, PHD

Occupation:

Assistant Professor, School of Nursing, University of Wisconsin, Milwaukee, USA.

Recent Publications: Artificial personhood: nursing ethics in a medical world, Nursing Ethics 2(3): 186-96, 1995. The ethics in the work of acting for patients, Advances 
in Nursing Science, 18(2): 1-12, 1995. Knowing the patient?, in Thorne, S. and Hayes, V. (eds) Nursing Praxis: Knowledge and Action, pp. 23-38 (Thousand Oaks, CA: Sage, 1997). The moral geography of home care, Advances in Nursing Science, 17(2): 18-26, 1994.

\section{Philip J. Ross}

BA(HONS), PHD

Occupation:

Lecturer, Faculty of Social, Health, Environmental and Life Sciences, University College of Ripon and York St John.

Recent Publications: De-privatising Morality (Aldershot: Avebury, 1994). Utility, subjectivism and moral ontology, Journal of Applied Philosophy, 11(2): 189-99, 1994.

\section{Simon Woods}

RGN, BA(HONS) (PHD CANDIDATE)

Occupation: Macmillan Lecturer in Cancer Nursing, University of Liverpool.

Recent Publications: Cancer care and the moral implications of altered appearance, in de Beaufort I., Hilhorst, M. and Holm, S. (eds) In the Eye of the Beholder, Ethics and Medical Change of Appearance, pp. 197-205 (Copenhagen: Scandinavian University Press, 1996). 